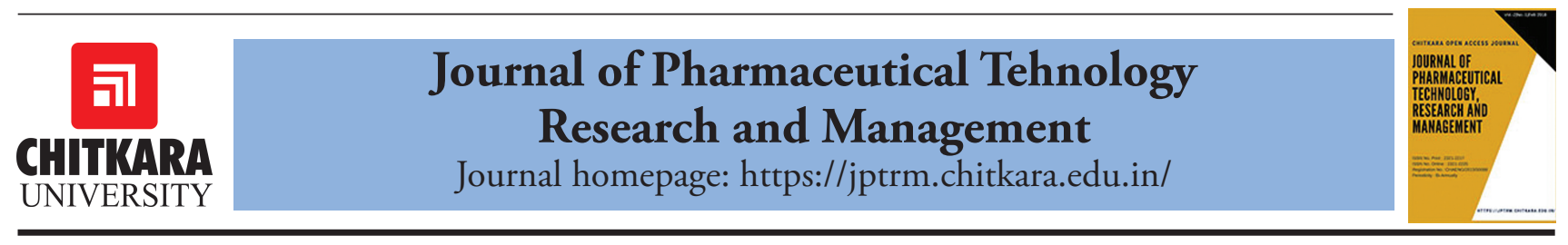

\title{
Exploring RP-HPLC Method for analysis of Axitinib in Bulk and in-house Tablets
}

\author{
Shailesh S Chalikwar ${ }^{1}$, Satish D Kayande ${ }^{1}$, Inderbir Singh ${ }^{2}$ and Atul A Shirkhedkar ${ }^{1 *}$ \\ ${ }^{1}$ R.C. Patel Institute of Pharmaceutical Education and Research, Shirpur 425405 Dist. Dhule (MS), India. \\ ${ }^{2}$ Chitkara College of Pharmacy, Chitkara University, Rajpura 140401, Patiala Punjab, India \\ *Email: shirkhedkar@gmail.com
}

\section{ARTICLE INFORMATION}

Received: June 26, 2018

Revised: Aug. 30, 2018

Accepted: Oct. 31, 2018

Published online: Nov 02, 2018

Keywords:

Axitinib;HPLC; validation;in-house tablets

\section{ABSTRACT}

Axitinib is a tyrosine kinase Inhibiter. In a commenced analysis, a effortless and responsive high-performance liquid-chromatography method was developed and validated for the quantitative estimation of Axitinib in bulk and in-house tablet dosage form. The present method was developed and validated using LC-GC Qualisil BDS C18 $(250 \mathrm{~mm} \times 4.6 \mathrm{~mm}, 5 \mu \mathrm{m})$. The separation of Axitinib was employed using a methanol: water $85: 15 \% v / v$ as a mobile phase at optimal flow rate $1 \mathrm{~mL} /$ min and column oven temperature $30^{\circ} \mathrm{C}$. While, Axitinib was examined at $330 \mathrm{~nm}$ with a photo diode array detector; retention timewas found to be 3.23 min. The intended method was validated by ICH rules for the accuracy, precision, sensitivity, and ruggedness. The linearity was followed in the concentration range of $4-24 \mu \mathrm{g} /$ $\mathrm{mL}$ as demonstrated by correlation coefficient $\left(r^{2}\right)$ of 0.9994 . The robustness of proposed method was assessed by purposelyvarying the chromatographic conditions. Consequently, the intended method can routinely be subjected for the estimation of Axitinib in bulk and in tablets formulation. and Sumantha, 2017), UPLC(Chakravarthy et al., 2016), spectrophotometric(Panda et al., 2016) and HPLC (Chandra and Sarada, 2016; ICH, 2005). To our knowledge, till date no HPLC method has been reported for the assurance of Axitinib in bulk and in-house tablet dosage form. Therefore, an attempt of proposed work is toestablish a simple, reliable and reproducible RP-HPLC method for determination of Axitinib in bulk and in-house tablet dosage form. Also, an established method wasvalidated in accordance with $\mathrm{ICH}$ guidelines Q2(B).

\section{Experimental}

\subsection{Chemicals and Reagents}

The materials and reagents used during the analysis, Axitinib were gotten as a gift sample from Glenmark Pharmaceutical Ltd, Mumbai, India, methanol (HPLC grade)were obtained from Merck Ltd Mumbai. Milli-Q distilled water was utilized. 


\subsection{Instrumentation}

Agilent (1260 series) HPLC system furnished with quaternary reservoirs and gradient system pump. Photo diode array detector and CTO 10 AS vp; column oven, a Rheodyne injector with $20 \mu \mathrm{L}$ loops and a Hamilton syringe $(100 \mu \mathrm{L})$ and analysis were performed with Open Lab panel Control (Agilent 1260) Germany. All weighing process for the studied analysis were accomplished with the help of SHIMADZU AUX-120 analytical balance. Ultra sonication of samples was achieved usingUltrasonicator; Enertech Electronics Pvt. Ltd., India.

\subsection{Preparation of Mobile Phase}

A mixture of methanol and water was prepared in the volume ratio of $(85: 15 \% v / v)$ as mobile phase. It was filtered through $0.4 \mu \mathrm{m}$ membrane filter paper andit was sonicated in an ultrasonicator for $20 \mathrm{~min}$.

\subsection{Preparation of Standard Stock Solution}

Accurately $10 \mathrm{mg}$ of Axitinib was weighed and transferred into $100 \mathrm{ml}$ of volumetric flask and volume was made up to the mark with the same to achieve concentration of $100 \mu \mathrm{g} / \mathrm{ml}$. From the stock solution, anappropriate volume of solution was withdrawn and diluted to $10 \mathrm{ml}$ with the same to achieve concentration of $10 \mu \mathrm{g} / \mathrm{ml}$.

\subsection{Preparation of in-house tablets}

Since, the finished pharmaceutical dosage formof Axitinib was not available in local Indian market, Therefore, in-house tablet containing $5 \mathrm{mg}$ of Axitinib were prepared with direct compression method using common excipients. Prepared in-house tablets are used as pharmaceutical formulation for rest of analysis.

\subsection{Preparation of Sample Solution}

The sample solution was prepared from in-house formulated Axitinib tablets. Twenty in-house tablets were accurately weighed, average weighed determined finely powered. A quantity of powered drug equivalent to $5 \mathrm{mg}$ Axitinib transferred into $100 \mathrm{ml}$ of volumetric flask containing $50 \mathrm{ml}$ methanol, sonicated for $15 \mathrm{~min}$. Further, the volume of the flask was made up to mark with the same solvent. The resulting solution was filtered through a $0.45 \mu \mathrm{m}$ filter (Millifilter, Milford, MA, USA). An accurate volume was further diluted with the methanol to obtain a concentration of $10 \mu \mathrm{g} / \mathrm{ml}$.

\subsection{Chromatographic Conditions}

The separation of Axitinib was performed on LC-GC Qualisil BDS C18(250 mm $\times 4.6 \mathrm{~mm}, 5 \mu \mathrm{m})$ using a mixture of methanol and water in the ratio of (85: $15 \%$ $v / v)$ as a mobile phase. Flow rate was maintained at $1 \mathrm{ml} /$ min. The PDA detection was employed at $330 \mathrm{~nm}$ and all analysis wasperformed at column oven temperature $30^{\circ} \mathrm{C}$. The chromatographic conditions of proposed analysis were shown in Table 1.

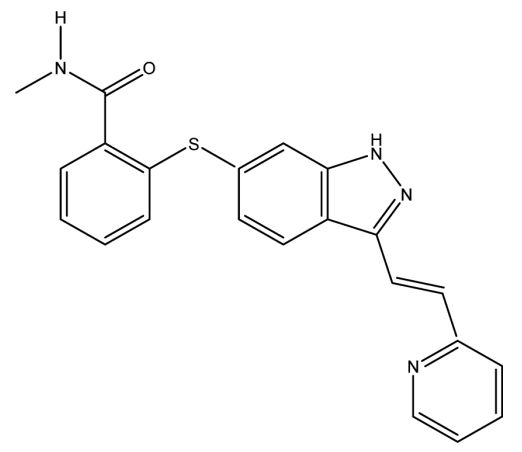

Figure 1: Chemical Structure of Axitinib.

Table 1: Chromatographic Conditions

\begin{tabular}{ll}
\hline HPLC System & $\begin{array}{l}\text { HPLC System (1260 series) Agilent, } \\
\text { Germany }\end{array}$ \\
\hline Detector & photo diode array \\
Column & LC-GC Qualisil BDS C18 \\
Dimensions & $(250 \mathrm{~mm} \times 4.6 \mathrm{~mm}, 5 \mu \mathrm{m})$ \\
Mobile Phase & Methanol: water $(85: 15 \% \mathrm{v} / \mathrm{v})$ \\
Mode & Isocratic \\
Flow Rate & $1.0 \mathrm{ml} / \mathrm{min}$ \\
Temperature & Ambient temperature \\
Detection wavelength & $330 \mathrm{~nm}$ \\
Injection Volume & $20 \mu \mathrm{L}$ \\
\hline
\end{tabular}

\subsection{Study of Calibration Curve}

The standard calibration curve was acquired by plotting the peak area versus concentration showed linear relationship over a concentration range of $4-24 \mu \mathrm{g} / \mathrm{mL}$, respectively. The linear regression equation for Axitinib was established as $\mathrm{y}=14485 \mathrm{x}$ +1955.7 and the regression coefficient value $\left(\mathrm{r}^{2}\right)=0.9994$ for drug indicating high degree of linearity. Characteristic parameters of the RP-HPLC method are reported in Table 2 and standard calibration curve is shown in Fig. 3 .

\section{Results and Discussion}

\subsection{Optimization of Chromatographic Conditions}

Selection of the optimum mobile phase composition for Axitinib determination was based on several trials. First, methanol and water in the ratio of $(50: 50 \% v / v)$ were tested; 
it was observed that Axitinib was not eluted. Therefore, the mobile phase composition was revised to methanol and water in the ratio of $(60: 40 \% v / v)$ and $(70: 30 \% v / v)$ was tested and these gave long retention time of drug. Finally, mobile phase consisting of methanol: water $(85: 15 \% v / v)$ showed good resolution of peak and the total run time was $10 \mathrm{~min}$ and the peak is optimized in $3.23 \mathrm{~min}$, Ahead of analysis mobile phase mixture and sample solutions were filtered over a $0.45 \mu \mathrm{m}$ membrane filter and ultra-sonication for $10 \mathrm{~min}$. Chromatographic investigation was executed at ambient temperature, flow rate was $1.0 \mathrm{ml} / \mathrm{min}$ with injection volume $20 \mu \mathrm{L}$ followed by detection wavelength at $330 \mathrm{~nm}$. The different trials executed out for optimization of mobile phase is shown in Fig. 2.

Table 2: System suitability studies.

\begin{tabular}{ll}
\hline Retention time & $3.23 \mathrm{~min}$ \\
\hline Capacity factor & 2.52 \\
Theoretical plate & 2775 \\
Tailing Factor & 1.54 \\
\hline
\end{tabular}

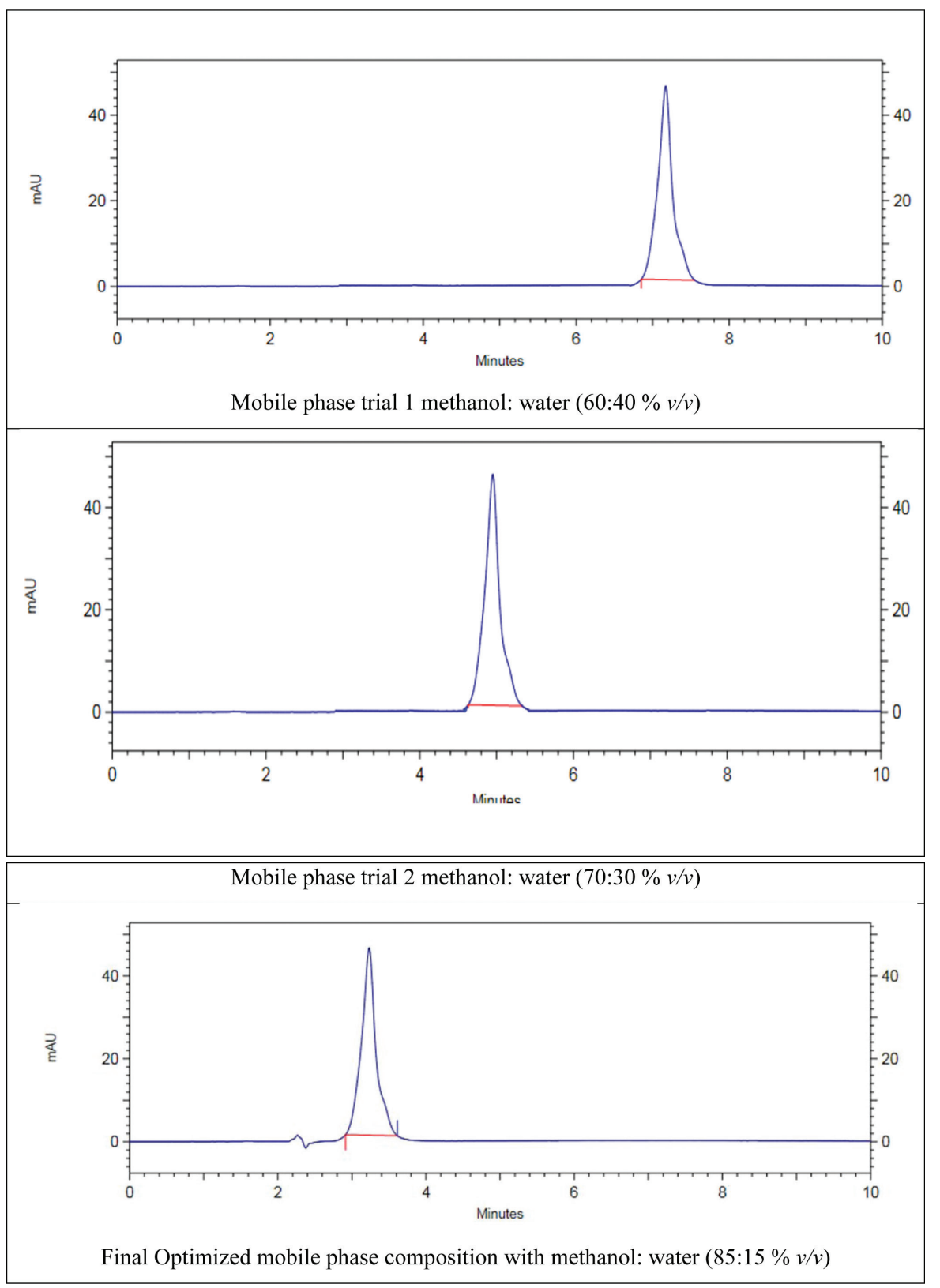

Figure 2: Different trials to optimize mobile phase. 


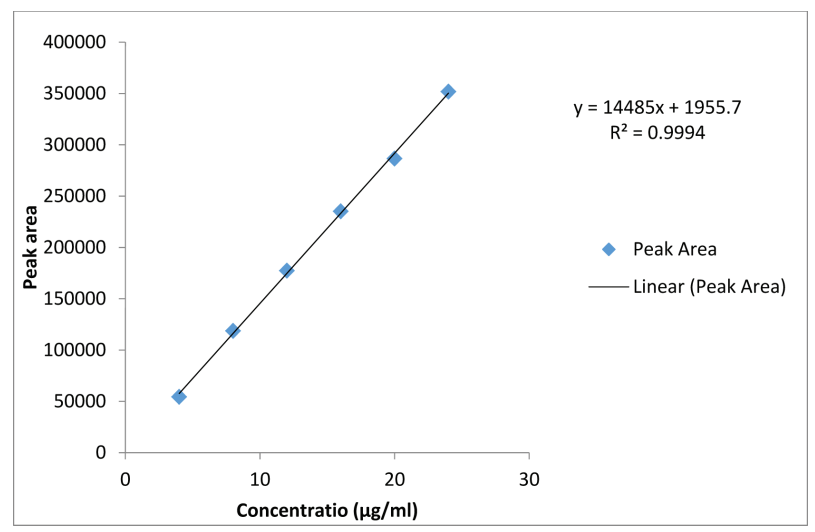

Figure 3: Standard Calibration Curve of Axitinib.

\subsection{Method Validation}

The anticipated method was validated in terms of precision, accuracy, limit of quantification (LOQ), Limit of Detection (LOD), specificity, ruggedness and robustness according to the international conference on harmonization (ICH) guidelines Q2(B)(ICH 2005).

\subsection{System suitability}

System suitability of proposed of method was performed using the concentration of $10 \mu \mathrm{g} / \mathrm{mLf}$ for Axitinib. Mean, standard deviation (SD) and percent relative standard deviation (\%RSD) were calculated for peak are and retention time. The \% RSD values for both peak area and retention time was established to be within the limit. The result of system suitability was shown in Table 3.

Table 3: Characteristics parameter of the HPLC method for determination of Axitinib.

\begin{tabular}{ll}
\hline Parameter & Axitinib \\
\hline Linearity range $\mu \mathrm{g} / \mathrm{mL}$ & $4-24 \mu \mathrm{g} / \mathrm{mL}$ \\
Slope & 14485 \\
Intercept & 1955.7 \\
Correlation Coefficient & 0.9994 \\
\hline
\end{tabular}

\subsection{Accuracy and Precision}

The accuracy of ananticipated analysis was assessed by standard addition methods, where a known amount of the standard was added in three different levels i.e. 80, 100 , and $120 \%$ to in-house tablet formulation of Axitinib. The experiment was performedin triplicate and percentage recoveries and \% RSD were calculated. The achieved \% recovery and \% relative standard deviation were within the range of $98.45-100.03 \%$ and $0.16-0.36$ agreeable the approved conditions for the studies. The results of $\%$ recovery study for Axitinib was shown in Table 4.

Table 4: Accuracy Studies.

\begin{tabular}{lccccc}
\hline Drug & $\begin{array}{c}\text { Initial Amount } \\
{[\boldsymbol{\mu g} / \mathbf{m L}]}\end{array}$ & $\begin{array}{c}\text { Excess drug added } \\
\text { to the analyte [\%] }\end{array}$ & $\begin{array}{c}\text { Total amount } \\
\text { found } \pm \text { S.D. } \\
{[\boldsymbol{\mu g} / \mathbf{m L}]}\end{array}$ & $\begin{array}{c}\text { Recovery }[\%] \\
{[\mathbf{n}=3]}\end{array}$ & $\begin{array}{c}\text { \%RSD } \\
{[\mathbf{n}=3]}\end{array}$ \\
\hline \multirow{3}{*}{ Axitinib } & 8 & 80 & $14.49 \pm 0.03$ & 100.03 & 0.30 \\
& 8 & 100 & $15.95 \pm 0.02$ & 99.69 & 0.16 \\
\hline
\end{tabular}

n- number of determinations

Table 5: Precision Studies [Intra and Inter-day].

\begin{tabular}{cccc}
\hline $\begin{array}{c}\text { Standard Concentration } \\
{[\mu \mathrm{g} / \mathbf{m L}]}\end{array}$ & $\begin{array}{c}\text { Amount Found } \\
{[\mu \mathrm{g} / \mathbf{m L}]}\end{array}$ & $\begin{array}{c}\text { \% Amount found }[\boldsymbol{\mu g} / \mathbf{m L}] \\
{[\mathbf{n}=\mathbf{3}]}\end{array}$ & \% RSD \\
\hline \multicolumn{3}{c}{ Intra-day Precision } \\
\hline 8 & 7.84 & 98.04 & 0.69 \\
12 & 11.91 & 99.28 & 0.45 \\
16 & 15.92 & 99.52 & 0.18 \\
\hline 8 & Inter-day Precision & 98.96 & 0.37 \\
12 & 7.91 & 99.45 & 0.49 \\
16 & 11.93 & 99.47 & 0.49 \\
\hline
\end{tabular}

$\mathrm{n}$ - number of determinations 
Precision of intended method was carried out as repeatability and intra-day and inter-day variations. The repeatability of method was controlled by performing six repeat estimations of $12 \mu \mathrm{g} / \mathrm{mL}$; the effects on the results were studied in terms of \% RSD and found to be less than 2 .

Intra-day variation was performed by analyzing three different concentrations for three times within a day and Inter-day precision was assessed by three different concentrations for three consecutive different days, over a period of week The intra-day and inter-day variation were measured at three different concentrations 8,12 and $16 \mu \mathrm{g} / \mathrm{mL}$. The effects on results of intra-day and inter-day variations were assessed in terms of \% RSD; and results were shown in Table 5.

\subsection{Limit of Quantification and Limit of Detection}

The LOD and LOQ were calculated using equations; LOD $=3.3 \times \mathrm{N} / \mathrm{B}$ and $\mathrm{LOQ}=10 \times \mathrm{N} / \mathrm{B}$, where, $\mathrm{N}$ is standard deviation of the peak areas of the drugs $(n=3)$, taken as a measure of noise, and ' $\mathrm{B}$ ' is the slope of the corresponding calibration curve. The LOD and LOQ for Axitinib were found to be $0.0199 \mu \mathrm{g}$ and $0.0602 \mu \mathrm{g}$, respectively. The obtained LOD and LOQ values showed the higher sensitivityto the optimized mobile phase mixture.

\subsection{Specificity}

Specificity study is a practice to measure quantitatively the analyte in existence of constituent that may be likely to be

Table 6: Analysis of in-house Tablets.

\begin{tabular}{cccc}
\hline Drug & $\begin{array}{c}\text { Amount taken } \\
{[\boldsymbol{\mu g} / \mathbf{m L}]}\end{array}$ & $\begin{array}{c}\text { Amount found } \\
{[\boldsymbol{\mu g} / \mathbf{m L}]}\end{array}$ & $\begin{array}{c}\text { \% } \\
\text { Amount found }\end{array}$ \\
\hline 12 & 11.81 & 98.46 \\
12 & 11.80 & 98.39 \\
12 & 11.81 & 98.42 \\
Axitinib & 12 & 11.81 & 98.48 \\
& 12 & 11.73 & 97.81 \\
& 12 & 11.77 & 98.15 \\
& Mean \pm SD & $11.79 \pm 0.031$ & $98.28 \pm 0.239$ \\
& \% RSD & 0.26 & 0.24 \\
\hline
\end{tabular}

$\mathrm{n}$-number of determinations

\subsection{Comparison of assay method with reported methods}

The assay, of the proposed RP-HPLC method was compared with the two reported methods. Further, the accuracy and there in the sample matrix. The results of specificity study revealed that the there was no other interfering peak around the retention time of drug.

\subsection{Robustness and Ruggedness}

Robustness of the method was established to evaluate the influence of small but purposeful dissimilarity in the chromatographic conditions for the determination of the percentage of Axitinib. The independent variables were selected for robustness studies include mobile phase volume, mobile phase composition, and column oven temperature and flow rate. Robustness of the method was performed at a concentration level of $8 \mu \mathrm{g} / \mathrm{mL}$. When very small changes were made to the method conditions there were no marked changes in chromatographic behavior and content of the drug, as evident from the low value of percentage RSD indicating the method is robust. Ruggedness of established method was by using two different analysts under the same experimental and environmental conditions. The results of ruggedness study revealed that value of percentage RSD was below $2.0 \%$, showed ruggedness of developed analytical method.

\subsection{Assayofin-house Axitinib Tablet Formulation}

Assay of in-house Axitinib tablet containing $5 \mathrm{mg}$ of Axitinib along with common excipients performed at concentration of $12 \mu \mathrm{g} / \mathrm{mL}$. The amounts of Axitinib determined were found to be $98.28 \pm 0.239 \%$. An excellent amount of recovery showed that there was no interference from the excipients present in the in-house tablet dosage form. Assay results for Axitinib in in-house tablet was represented in Table 6. sensitivity of the developed method was compared with reported methods. The results of the proposed RP-HPLC and reported methods were found to be comparable; shown in Table 7. 
Table 7: Comparison of established method with reported HPLC methods [3, 9].

\begin{tabular}{clcccc}
\hline Sr. No & Validation parameters & $\begin{array}{c}\text { Proposed RP-HPLC } \\
\text { Method }\end{array}$ & $\begin{array}{c}\text { Reported } \\
\text { Method 1 }\end{array}$ & $\begin{array}{c}\text { Reported } \\
\text { Method 2 }\end{array}$ & Comments \\
\hline 1. & Accuracy (\%) & $98.45-100.03$ & $99.37-99.87$ & $98.7-100.3$ & Good accuracy \\
2. & LOD and LOQ ( $\mathbf{\mu g})$ & 0.0199 and 0.0602 & 0.62 and 1.88 & 0.06 and 0.17 & Comparable sensitivity \\
3. & Assay (\%) & 98.28 & 99.63 & 100.26 & $\begin{array}{l}\text { Comparable assay } \\
\text { results }\end{array}$ \\
\hline
\end{tabular}

\section{Conclusion}

The proposed developed RP-HPLC method for the estimation of Axitinibin bulk and in-house tablet dosage form using mobile phase composed of methanol: water $(85: 15 \% v / v)$ showed an admirable separation of Axitinib with retention time was $3.23 \mathrm{~min}$. The established method gives good resolution of Axitinib with short analysis time. The established method was linear over the concentration range of $4-24 \mu \mathrm{g} / \mathrm{ml}$; with a correlation coefficient $\left(\mathrm{r}^{2}\right)$ 0.999 along with the obtained LOD and LOQ $0.0199 \mu \mathrm{g}$ and $0.0602 \mu$ gvalues showed the highest sensitivity towards the optimized mobile phase. The method was developed and validated and found to be simple, sensitive, accurate, and precise. Also, the developed methods were compared with the reported methods. Therefore, thedeveloped method can be routinelyused for the analysis of Axitinib in bulk and inhouse pharmaceutical dosage form.

\section{Acknowledgement}

Authors are thankful to Principle, R. C. Patel Institute of Pharmaceutical Education and Research, Shirpur (MS) India,for providing necessary facilities to carry out the research work.

\section{Conflict of Interest}

The authors declare no potential conflict of interest

\section{References}

1. Pithavala, Y. K., Chen, Y., Toh, M., Selaru, P., Labadie, R. R., Garrett, M., Hee, B., Mount, J., Ni, G., Klamerus, K. J. and Tortorici, M. A. et al., (2012). Evaluation of the effect of food on the pharmacokinetics of axitinib in healthy volunteers. Cancer Chemotherapy and Pharmacology, 70(1), 103-112. https://doi.org/10.1007/s00280-012-1888-9

2. Lakshmi, B., Saraswathi, K., Reddy, T. V., (2012). RPHPLC method development and validation for the analysis of Axitinib in pharmaceutical dosage forms.
International Journal of Science Innovations and Discoveries, 2, 184-90.

3. Chandra, R. B. J. and Sarada, N. C. (2016). Development and validation of Stability indicating RP-HPLC method for the Determination of Axitinib in Bulk and its Pharmaceutical Formulations. Der Pharmacise Letter, 8(11), 97-106.

https://www.drugbank.ca/drugs/DB06626

4. Wilmes, L. J., Pallavicini, M. G., Fleming, L. M., Gibbs, J., Wang, D., Li, K. L., Partridge, S. C., Henry, R. G., Shalinsky, D. R., Hu-Lowe, D., Park, J. W., McShane, T. M., Lu, Y., Brasch, R. C., Hylton, N. M. et al., (2007). A novel inhibitor of VEGF receptor tyrosine kinases, inhibits breast cancer growth and decreases vascular permeability as detected by dynamic contrast-enhanced magnetic resonance imaging. Magnetic Resonance Imaging, 25, 319-327.

https://doi.org/10.1016/j.mri.2006.09.041

5. Bouchet, S., Chauzit, E., Ducint, D., Castaing, N., Canal-Raffin, M., Moore, N., Titier, K., Molimard, M., et al., (2011). Simultaneous determination of nine tyrosine kinase inhibitors by 96-well solid-phase extraction and Ultra Performance LC/MS-MS. Clinica Chimica Acta, 412, 1060-1067.

https://doi.org/10.1016/j.cca.2011.02.023

6. Lankheet, N. A., Hillebrand, M. J., Rosing, H., Schellens, J. H., Beijnen, J. H. and Huitema, A. D., (2013). Method development and validation for the quantification of dasatinib, erlotinib, gefitinib, imatinib, lapatinib, nilotinib, sorafenib and sunitinib in human plasma by liquid chromatography coupled with tandem mass spectrometry. Biomedical chromatography, 27(4), 466-476.

https://doi.org/10.1002/bmc.2814

7. Sparidans, R. W., Iusuf, D., Schinkel, A. H., Schellens, J. H., Beijnen, J. H. (2009). Liquid chromatographytandem mass spectrometric assay for the light sensitive tyrosine kinase inhibitor axitinib in human plasma. Journal of Chromatography B, 877(32), 4090-6. https://doi.org/10.1016/j.jchromb.2009.10.024

8. Gorja, A. and Sumantha, M., (2017). Development and validation of Stability indicating method for the estimation of Axitinib in tablet dosage form by UPLC. 
Indian Journal of Pharmaceutical and Biological Research, 5(3), 1-6.

9. Chakravarthy, V. A. and Sailaja, B. B. V., (2016). Method development and validation of UVspectroscopic method for the estimation of assay of anti-cancer drugs-axitinib, bosutinib, erlotinib hydrochloride, gefitinib and pemetrexed disodium drugs in api form. European Journal of Pharmaceutical and Medical Research, 3, 609-624.
10. Panda, S. S., Bera, V. V. R. K., Panda, N., (2016). Development and Validation of a Superior High Performance Liquid Chromatographic Method for Quantification of Axitinib in Solid Oral Dosage Form. American Journal of Modern Chromatography, 3, $33-43$. https://doi.org/10.7726/ajmc.2016.1003

11. ICH Q2B (2005). Validation of analytical procedure; methodology, federal register. 1196(60), 27464. 